\title{
International Legal Regulation and Supranational Interaction in Counteracting the COVID-19 Pandemic: Challenges and Proposals
}

\author{
Ievgenii Shulga ${ }^{\star 1}$, Zoryana Skaletska ${ }^{2}$, Olena Kalaianova ${ }^{3}$, Oleksandra Shynkaruk ${ }^{4}$ \\ ${ }^{1}$ Department of International Law and Comparative Law, National University of Life and Environmental Sciences of \\ Ukraine, 03041, Kyiv, Ukraine. Email: evshulga2013@gmail.com | ORCID: 0000-0002-9343-8647 \\ ${ }^{2}$ Department of European and International Law, National University "Kiyv-Mohyla academy", Hryhoriya \\ Skovorody St., 2, 04655, Kyiv, Ukraine. Email: chernenko@ukma.edu.ua | ORCID: 0000-0001-9162-4836 \\ ${ }^{3}$ Department of Criminology and Psychology, Odessa State University of Internal Affairs, Uspenska St., 1, 65000, \\ Odesa, Ukraine. Email: olenakalaianova@gmail.com | ORCID: 0000-0003-3882-2192 \\ ${ }^{4}$ Department of Philosophy and International Communication, National University of Life and Environmental \\ Sciences of Ukraine, 03041, Kyiv, Ukraine. Email: aleksandra.shyn5@gmail.com | ORCID: 0000-0002-5494-1370 \\ ${ }^{\star}$ Corresponding author
}

\section{ABSTRACT}

The purpose of the article is to study problems of international legal regulation and supranational cooperation in combating the COVID-19 pandemic. The institutional and international legal mechanism of counteraction to the spread of the pandemic is analyzed. The problem moments of realization of provisions of the main international acts in the area of counteraction to the Coronavirus disease by the national governments are marked out. The methodological basis for the article is general and special methods and techniques of scientific knowledge, in particular: formal-logical, Aristotelian method, method of documentary, system-structured method, formal and legal method, forecasting method, method of generalization. The key problems of international legal counteraction to the pandemic spread are as follows: advisory (not obligatory) character of the majority of international legal acts related to the fight against COVID-19; disinterest of the states in timely informing WHO about the outbreaks of infectious diseases; arbitrary interpretation of the international acts by national governments; human rights restrictions on the movement imposed by the states; lack of a clear funding mechanism to build the necessary global and national infrastructure to ensure commitment in accordance with the International Health Regulations.

Keywords: International law; Covid-19; Supranational cooperation; Human rights
Received: 31 July 2021

Reviewed: 05 August 2021

Accepted: 06 August 2021

Published: 10 August 2021

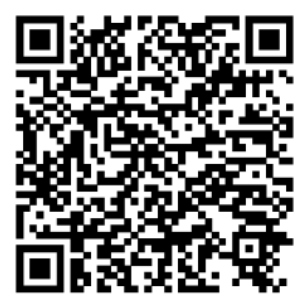

How to cite this paper: Shulga, I., Skaletska, Z., Kalaianova, O., \& Shynkaruk, O. (2021). International Legal Regulation and Supranational Interaction in Counteracting the COVID-19 Pandemic: Challenges and Proposals. Journal of Policy \& Governance, 01(01), 54-62. https://doi.org/10.33002/jpg010105

Copyright (C) 2021 by author(s). This work is licensed under the Creative Commons Attribution International License (CC BY 4.0). http://creativecommons.org/licenses/by/4.0/

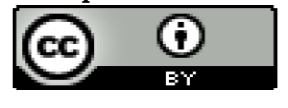




\section{INTRODUCTION}

Today, the global society is facing increasing challenges from the spread of infectious diseases. Over the past few decades, the world has faced such strains as Bird Flu (H5N1), Grippus Suum (H1N1), Febris Ebola (EBOV) and others. However, the most widespread so far is the spread of Covid-19 (SARS$\mathrm{CoV}-2$ ), the consequences of the spread have a transboundary character and have already manifested themselves in the social sphere and various sectors of the economy of many countries. On March 11,2020, the World Health Organization (WHO) announced that the COVID-19 virus epidemic had reached pandemic level (World Health Organization, 2020a).

The rapid spread of the COVID-19 pandemic contains a number of threats from ensuring the national security of each individual state, interstate economic and political relations to respecting and protecting human rights. COVID-19 has been spreading around the world for over a year and is taking the lives of millions of people (Worldometers, 2021). The rapid spread of the new strain and the threats it poses to human life and health have brought the issue of pandemic to an international level. Now the international counteraction to the COVID-19 is a key task of international governmental (United Nations, World Health Organization, International Monetary Fund, World Bank, European Central Bank, etc.) and non-governmental (International Red Cross and Red Crescent Movement, Doctors Without Borders, Wild4Life, BRAC, etc.) organizations. Cooperation between international organizations and national governments is carried out mainly on the basis of coordination and recommendations. At the same time, direct implementation of anti-epidemic measures, management in the sphere of counteraction to the spread of the pandemic is the task of national governments implementing administrative restrictive anti-epidemic measures aimed at preventing the spread of COVID-19. Counteracting the spread of the pandemic through the administration of restrictive, antiepidemic measures and vaccination of the population remain one of the most effective ways to prevent new infections.

The goal of this article is to study problems of international legal regulation and supranational cooperation in combating the COVID-19 pandemic.

\section{RESEARCH METHODS}

A set of methods were used to compile the article. The peculiarities of the research structure of the article are determined by a combination of legal and formal-logical methods that allow to achieve its goal. The aristotelian method allowed, based on the study of statistical literature, institutional menhanism to describe in detail and systematically the nature of international legal and supranational cooperation in the field of counteraction to the spread of pandemic COVID-19. Under the influence of the method of documentary analysis, it became possible to analyze the provisions of international legal acts on the essence of their provisions to counter the spread of the pandemic. Use of system-structured method helped to investigate the essence of available international legal countermeasures and their implementation by national governments of the states. The formal and legal method and the forecasting method made it possible to clarify the major problem points in the international legal regulation of combating the spread of infection and to highlight the prospects for their further improvement. Several other general and special methods of scientific knowledge were used in the work that allowed a thorough and comprehensive approach to the implementation of our study.

\section{LITERATURE REVIEW}

Different issues related to international legal regulation and supranational cooperation in an attempt to counter the COVID-19 pandemic have been studied by a number of scholars. Habibi et al. (2020) studied violations of the international health regulations during the COVID-19 pandemic. The authors conclude that upholding the rule of international law is needed now more than ever. Countries can start by rolling back illegal travel restrictions that have already been implemented and by supporting WHO and each other in implementing the International Health Regulations, 2005 (IHR).

Pevehouse (2020) examined populist ideology, which sheds light on some of the difficulties in disentangling the various individual-level ideologies and attitudes that hang together around international cooperation. In his work the author has argued that understanding the mechanisms by 
which populism influences international cooperation is an important avenue of research for this topic.

The States' Duties to Prevent and Halt the Coronavirus Outbreak were analized by Dias \& Coco (2020). In the conclusion, scholars noted that with origins dating back to the 19th century, due diligence remains a fundamental principle of international law. To the extent that they can, states must do more to stop this outbreak and prevent it from spreading further and reappearing in recovered areas. In particular, according to the International Health Regulations, 2005, states should continue to closely monitor the development of the disease with efficient testing and to prepare for the worst-case scenario.

Villarreal (2020) resumes that states by deviating from the WHO's advice fail to fulfill their obligations under the IHR. In his opinion, article 43 of the International Health Regulations, 2005 (IHR) ${ }^{1}$, which regulate relations between international and national authorities, in general is not 'hard-and-fast' in the sense that disregarding the WHO's recommendations lead to a violation per se. Gostin (2004) in his scientific work focused on specific problems of international infectious disease law. The author claims that the WHO should ensure state compliance with health norms and generous economic and technical assistance to poorer countries. An important issue for the international community is how sovereign countries can join together to make global health work for everyone, the poor and the wealthy alike.

Milanovic (2020) highlighted as a separate problem the viral misinformation and the freedom of expression. At the same time, the researcher believes that the suppression of misinformation, on COVID19 or some other issue, by state and corporate entities can at best be a mitigating strategy. They are not effective enough for the ultimate goal that they are pursuing, especially when there are serious structural problems in societies that create fertile ground for misinformation. Kurbatov \& Rogozha (2020) also made stress on ethical dimensions of COVID-19 pandemic situation and its influence on development of educational and other practices at national and global level.

The new strain of COVID-19 virus is causing an imbalance in the body's immune response by infiltrating body cells, making its own copies of host new cells, which is extremely dangerous to human health (Gallagher, 2020). The first case of infection was recorded in the city of Wuhan, China, in late 2019, but a timely failure to implement administrative restrictions and a lack of global awareness caused the virus to spread to other nations and continents. Today, the WHO, as the main specialized organization in the field of health, officially recognizes the disease as a terrible pandemic and takes measures to coordinate and support states to prevent, detect and organize the fight against it. So, the organization created the Fund for assistance to the pandemic, developed international health regulations, adopted the updated strategy for combating COVID-19 with a number of recommendations and other activities (World Health Organization, 2020b).

The main international act in the sphere of fighting the pandemic is the new edition of the International Health Regulations (IHR) adopted by WHO in 2005 to prevent the global spread of diseases. Their prevention and control, taking a number of measures at public health level, which are adequate to public health risks, limited by them, and do not create unnecessary obstacles to international transport and trade. In accordance with the provisions of the IHR, the mechanism for combating COVID-19 includes two main steps. Step 1 relates to increasing the expressed obligations of state parties: a) the obligation to inform WHO about health risks regardless of the consent of the state; $b$ ) taking protective measures in strict accordance with the principle of respect for human rights and dignity; c) building the necessary capacity for timely identification, reporting and taking necessary actions in response to health risks, including establishment of national focal centers. Step 2 is connected with expanding the powers and obligations of the WHO: a) the right of the WHO to issue temporary and permanent recommendations to states where outbreaks of infectious diseases have been registered; $b$ ) the right to consider, in addition to information provided by official authorities, also information from nongovernmental sources, such as data from non-governmental organizations, media, Internet resources; c) the obligation to check the reliability and confidentiality of the information received (World Health Organization, 2005e).

The other important international act to counter the pandemic is the COVID-19 Strategy Update (hereinafter referred to as the Strategy), which provides for the use of organizational and legal measures by states, such as rapid detection, testing and treatment of patients with severe disease, mobilizing all structures and populations to fight the pandemic, suppressing transmission in the population, reducing mortality by providing appropriate clinical care to COVID-19 patients (World Health Organization, 2020c).

\footnotetext{
${ }^{1}$ International Health Regulations (2005). Retrieved from https://apps.who.int/iris/rest/bitstreams/52146/retrieve
} 
In addition, it is the responsibility of each country to develop and implement national strategies to combat the COVID-19 pandemic, including such areas as:

a) coordinating the national and regional response;

b) the involvement and mobilization of local communities affected by the virus and at risk;

c) applying contextually necessary medical and sanitary measures to slow down virus transmission and control sporadic cases;

d) preparing the health system to reduce COVID-19 related deaths, maintaining the priority of health services and protecting health workers;

e) emergency planning to ensure continuity of vital public functions and services (World Health Organization, 2020d).

It can be argued that the strategy acts as a kind of roadmap to combat the spread of the pandemic for national governments. However, as can be seen from the document these goals are rather abstract, and determine primarily the key areas of the international legal regulation of the spread of the virus creates a wide field for the implementation of the so-called "trial and error" system for national governments in accordance with their qualifications, democratic processes and financial capabilities.

\section{RESULTS AND DISCUSSION}

Analysis of the provisions of the Strategy shows that the above intergovernmental health organization entrusts national governments, represented by the ministries of health, with developing the components of the Strategy for combating Coronavirus infection and implementation of the International Health Regulations provisions on their own, giving only general guidelines. As a result, national governments can quite arbitrarily draft the provisions of the document. So, a series of measures, taken by the national governments in response to the pandemic COVID-19, violated the provisions of the IHR, which set the limits of the range of medical and sanitary measures. The states have the right to take, in conditions of public health risks, the measures, based on the scientific principles and data, which are comparable with the existing risks, and take into consideration the human rights. Thus, according to assessment of Habibi et al. (2020), the travel restrictions imposed were not based on scientific evidence or WHO guidance. It violates article 43, paragraph 2 of the IHR. The travel restrictions do not comply with article 43 , paragraph 1 , paragraph 5 , which requires that the measures should be no more restrictive than the available reasonable alternatives. Therefore, some measures are discriminatory, in violation of the principles laid out in article 3 of the IHR. The states often failed to comply with article 43, paragraph 3 and 5, which require WHO to provide information on restrictions imposed (Habibi et al, 2020).

Conversely, some states have not acted with sufficient diligence in preparing and counteracting the spread of the pandemic and have not always taken the necessary measures and followed WHO recommendations (Dias \& Coco, 2020). However, the legal consequences of states deviating from WHO recommendations remain open (Villarreal, 2020). The following factors also affect the effectiveness of implementation of the IHR and the Strategy:

1) challenges in implementation at the national level, which depend on the political will of states (manifested in states' disinterest in informing WHO in a timely manner about outbreaks of infectious diseases because of the possible prospect of loss of economic benefits, the possibility of future reservations, and the absence of a legally binding dispute resolution mechanism);

2) traditionally, WHO acts have been of a soft law nature, which may cause a negative attitude towards both the IHR as a whole and the recommendations issued on their basis by WHO, on the part of states;

3) new IHR are not aimed at preventing new infectious diseases and incorporate NOT preventive actions, but actions aimed at combating the consequences;

4) lack of an appropriate funding mechanism, which would allow to create the necessary global and national infrastructure to ensure obligations in accordance with the IHR, including assisting the least developed countries in building their own capacity (Gostin, 2004).

It should also be noted that WHO is not the only international governmental organization that coordinates the regulatory and legislative actions of national governments. Thus, the issue of developing principles and fundamental principles of international cooperation against the pandemic has been repeatedly put on the agenda of the UN General Assembly, resulting in a number of resolutions on combating the spread of COVID-19. Thus, Resolution 74/270 "Global Solidarity to Fight the Coronavirus 
Disease 2019 (COVID-19)"2 as of 02.04.2020 emphasized the central role of the UN in strengthening cooperation to take global measures to prevent and contain the spread of COVID-19. The resolution proclaimed the following:

(1) WHO has a crucial role in the fight against the spread of COVID-19;

(2) COVID-19 can be countered through global action based on unity, solidarity and active multilateral cooperation; the global response to the threat of COVID-19 must fully respect human rights and prevent discrimination, racism and xenophobia;

(3) There is a list of areas for international cooperation to be enhanced, such as sharing information, scientific knowledge and experience, including experiences in the implementation of the WHO recommendations and standards (United Nations, 2020a).

Resolution 74/274 "International cooperation to ensure global access to medicines, vaccines and medical equipment to face COVID-19" of 20.04.2020 co-authored by Ukraine establishes a model of cooperation between WHO and other relevant agencies in the UN common system, including international financial institutions. This embodies recommendations for operational scaling up of production, strengthening of supply chains that promote fair, transparent, equal, effective and timely access to prevention tools, laboratory tests, reagents and supporting materials, essential medical supplies, new diagnostic tools, medicines and future vaccines against COVID-19. The Resolution states that medical products should be available to all who need them, including developing countries (United Nations, 2020b). However, the provisions of this Resolution are quite difficult to implement, given the economic performance of states. Thus, countries with more developed economic potential are able to implement a wide range of measures from restrictions on the movement of citizens and their isolation to the implementation of compensatory policies. Less developed states have to consider the economic and social conditions of their citizens, while facilitating quarantine to provide opportunities to preserve workplaces and support small businesses.

The accumulated global experience of WHO and other international organizations within the UN system on COVID-19 and the development of recommendations, technical guidelines, resource management tools are presented in chronological order in a special "timeline: WHO's response to COVID-19" (World Health Organization, 2020d). However, the implementation of international legal measures to fight the pandemic are presented mainly in the form of restrictions. And in this case, there is a question of the correlation of the introduction of these quarantine restrictions with the observance of human rights. This issue arises in particular in the case of states of emergency or similar regimes, the imposition of which increases the powers of governments (sometimes also the police and the army) and reduces the powers of parliaments and the judiciary, with a serious blurring of the lines separating executive, legislative and judicial powers and may cause imbalances in the system of checks and balances that underlie democracy (European Parliament, 2020).

In general, international human rights standards guarantee everyone the right to the highest attainable standard of health and oblige states to take measures to prevent health threats and to provide health care to those who need it. At the same time, it is considered that the COVID-19 pandemic, which certainly reaches the level of threat to public health, may justify the restriction of certain rights and freedoms (European Union Agency for Fundamental Rights, 2020). However, these restrictions must be imposed on the basis of the rule of law, openness and transparency. They must meet the challenges and must be scientifically sound. Their application cannot be discriminatory and unlimited in time. In addition, restrictions must respect human dignity and human rights (United Nations, 2020c).

The application of measures aimed at countering the COVID-19 pandemic must not result in violations of people's rights to privacy, freedom from discrimination, freedom of information and freedom of expression (United Nations, 2020c). Such rights may be restricted; for example freedom of expression may be restricted in relation to the dissemination of false information, but any restrictions must balance human rights and the public interest. In the context of the COVID-19 pandemic, the state has a negative obligation "not to disseminate false information and a positive obligation to provide truthful, accurate and reliable information, as such information becomes an important part of combating the spread of the virus. At the same time, combating misinformation about the COVID-19 virus should not disproportionately limit freedom of the media" (Council of Europe, 2020).

\footnotetext{
${ }^{2}$ Resolution 74/270 "Global Solidarity to Fight the Coronavirus Disease 2019 (COVID-19)". Retrieved from https://documents-dds-ny.un.org/doc/UNDOC/GEN/N20/087/28/PDF/N2008728.pdf?OpenElement
} 
It is interesting, in our opinion, to analyze supranational cooperation within the framework of the EU, an economic and political association of states that was created to promote peace, democratic values and the well-being of citizens. Here we should note the key role of the European Commission in counteracting the spread of coronavirus disease, which, since January 2020, has adopted a series of power and administrative measures (Leyen, 2021a) to protect EU citizens from the threat of coronavirus. Namely, the Commission has activated the EU Civil Protection Mechanism and carried out the repatriation (return) of EU citizens. Interstate measures to protect the population, in particular travelers, industry, agriculture, transport, joint procurement of personal protective equipment and medical equipment, research on the new Coronavirus 2019-nCoV, regulations on measures related to health protection at borders to protect the health of citizens, while ensuring the proper treatment of people who have to travel and ensure the availability of essential goods and services, free movement of essential workers etc., and additional funding of the health care system. Full disclosure of information on cooperation, communications, activities and decisions of a medical and other nature in chronological order are reflected on the website of the Council of Europe (European Commission, 2021). At the same time, each state was left alone in counteracting the spread of the COVID-19, introducing its own list of quarantine measures. Instead of developing a unified plan of action mandatory for all members of the Union and creating international research centers, the EU funded Astra Zeneca with more than 300 billion Euros, which in the end narrowed the production of vaccines in one company, could not meet the needs of vaccination of citizens of the Union. Thus, to date, vaccine shortages and failed vaccination policies have resulted in a situation in which only $46 \%$ of the EU population received their first dose of vaccine (Leyen, 2021b). In other words, it is clear that the $\mathrm{EU}$, as a powerful supranational entity, has not created the conditions for the adoption of a clear mechanism for counteracting the spread of the COVID19 and dealing with its consequences. All this demonstrates the ineffectiveness of the supranational level of the fight against the spread of the COVID-19. The decrease in the level of internationalization of the strengthening role of the state in the Union affects the further predominance of national interests over the interests of communities.

A separate problem of internationalization today is countering disinformation, which is a threat to international and national information security. Thus, information attacks were repeatedly exposed to both the use of individual vaccines (Ministry of Health of Ukraine, 2021) and the vaccination process in general, which ultimately had a negative impact on the perception of vaccination by the population. It should be noted that the first step to counteract the spread of misinformation have already been taken, so recently the European Union adopted the Code of Practice against Disinformation (European Commission, 2021) and the Action Plan against Disinformation (European Commission, 2018). On the basis of these documents, it is necessary to develop international and national acts to counteract direct information threats during the pandemic COVID-19, should contain a system of clear and specific measures to counter disinformation manifestations associated with the pandemic, the organizational and legal status of subjects "objects of the fight against disinformation, the mechanism of liability, etc." It is also necessary to develop and implement state programs to improve information literacy among the population and economic entities in the media sphere. Disseminate information literacy skills by organizing educational events at schools, universities, and government institutions in the form of lectures, roundtables, online meetings, podcasts on Youtube, and social networks, involving journalism experts, government officials, law enforcement officials, scientists, etc.

\section{CONCLUSIONS}

The COVID-19 pandemic has become a significant challenge for the global community and has shown unpreparedness for a coordinated and effective counteraction to its spread. Among the major problems of the international legal response to the spread of the pandemic are: the recommendatory (nonbinding) nature of most international legal acts related to the fight against COVID-19; the lack of interest of states in informing WHO in time about the outbreak of infectious diseases for fear of losing economic benefits; arbitrary interpretation of the provisions of international acts by national governments, threatening to limit and violate human rights; restrictions on human rights of movement imposed by states were not based on scientific evidence or WHO guidance; lack of a clear funding mechanism that would allow the creation of the necessary global and national infrastructures to ensure obligations in accordance with the IHR, including assistance to the least developed countries in building their own 
capacity; lack of a clear mechanism to counteract disinformation manifestations associated with the COVID-19 and the like.

These problems characterize the current state of international legal regulation and supranational cooperation in counteracting the spread of COVID-19. Their solution in combination with the strengthening of the role of international institutions over national governments will increase the effectiveness of counteraction to the spread of the pandemic and the prevention of the spread of new strains of infectious diseases.

\section{REFERENCES}

Council of Europe (2020). Press freedom must not be undermined by measures to counter disinformation about COVID-19. Commissioner for Human Rights. Retrieved from https://www.coe.int/en/web/media-freedom/-/press-freedom-must-not-be-undermined-bymeasures-to-counter-disinformation-about-covid-19 [Accessed 05 April 2021]

Dias, T. S. \& Coco, A. (2020). Part III: Due Diligence and COVID-19: States' Duties to Prevent and Halt the Coronavirus Outbreak. Blog of the European Journal of International Law, 25 March 2020. Retrieved from https://www.ejiltalk.org/part-iii-due-diligence-and-covid-19-states-duties-toprevent-and-halt-the-coronavirus-outbreak [Accessed 03 April 2021]

European Commission (2018). Report on the implementation of the Action Plan Against Disinformation. Retrieved from https://op.europa.eu/en/publication-detail/-/publication/8a94fd8f-8e92-11e9-936901aa75ed71a1/language-en [Accessed 20 April 2021]

European Commission (2021). Code of Practice on Disinformation. Retrieved from https://digitalstrategy.ec.europa.eu/en/policies/code-practice-disinformation [Accessed 12 July 2021]

European Parliament (2020). The Impact of COVID-19 Measures on Democracy, the Rule of Law and Fundamental Rights in the EU. Monitoring Group on Democracy. Retrieved from https://www.europarl.europa.eu/RegData/etudes/BRIE/2020/651343/IPOL_BRI(2020)651343_EN .pdf [Accessed 20 April 2021]

European Union Agency for Fundamental Rights (2020) Coronavirus pandemic in the EU Fundamental Rights Implications. Bulletin 1. Retrieved from https://fra.europa.eu/sites/default/files/fra_uploads/fra-2020-coronavirus-pandemic-eu-bulletin1_en.pdf [Accessed 15 May 2021]

Gallagher, J. (2020). Coronavirus: What it does to the body. BBC News Ukraine. Retrieved from https://www.bbc.com/ukrainian/features-51886721 [Accessed 05 April 2021]

Gostin, L. O. (2004). International infectious disease law: revision of the World Health Organization's International Health Regulations. Jama, 291(21), 2623-2627.

Habibi, R., Burci, G. L., de Campos, T. C., Chirwa, D., Cinà, M., Dagron, S., \& Hoffman, S. J. (2020). Do not violate the International Health Regulations during the COVID-19 outbreak. The Lancet, 395(10225), 664-666. https://doi.org/10.1016/S0140-6736(20)30373-1

Kurbatov, S. V., \& Rohozha, M. M. (2020). University Mission in Western-European Culture (Ethical and Sociological Aspects) P. II. Filosofiya Osvity. Philosophy of Education, 26(1), 113130. https://doi.org/10.31874/2309-1606-2020-26-1-7

Leyen, U. (2021a). Nearly half of the population in the EU has received the first dose of COVID vaccine. Word and Action, Analytical Portal. Retrieved from https://www.slovoidilo.ua/2021/05/25/novyna/suspilstvo/yes-pershu-dozu-vakcyny-covidotrymala-majzhe-polovyna-naselennya [Accessed 20 June 2021]

Leyen, U. (2021b). We must look out for each other; we must pull each other through this. Timeline of EU action. Retrieved from https://ec.europa.eu/info/live-work-travel-eu/coronavirusresponse/timeline-eu-action_en [Accessed on 15 May 2021]

Milanovic, M. (2020). Viral Misinformation and the Freedom of Expression: Part III. Ejiltalk. Org, 1-5. Retrieved from https://www.ejiltalk.org/viral-misinformation-and-the-freedom-of-expressionpart-iii/ [Accessed 15 May 2021]

Ministry of Health of Ukraine (2021). The most common fakes about vaccination. Retrieved from https://moz.gov.ua/article/health/najposhirenishi-fejki-pro-vakcinaciju-vid-covid-19 [Accessed 14 July 2021] 
Pevehouse, J. C. (2020). The COVID-19 Pandemic, International Cooperation, and Populism. International Organization, 74(S1), E191-E212. https://doi.org/10.1017/S0020818320000399

United Nations (2020a). COVID-19 and Human Rights. The UN High Commissioner for Human Rights. Retrieved from https://news. un.org/ru/story/2020/03/1373871 [Accessed 05 April 2021]

United Nations (2020b). Resolution 74/274 entitled "International cooperation to ensure global access to medicines, vaccines and medical equipment to face COVID-19". The General Assembly. Retrieved from https://www.un.org/pga/74/2020/04/15/international-cooperation-to-ensure-global-access-tomedicines-vaccines-and-medical-equipment-to-face-covid-19/ [Accessed 15 April 2021]

United Nations (2020c). COVID-19: States should not abuse emergency measures to suppress human rights. UN experts. Retrieved from https://www.ohchr.org/RU/NewsEvents/Pages/DisplayNews.aspx?NewsID=25722\&LangID=R. [Accessed 20 April 2021]

Villarreal, P. (2020). Can They Really Do That? States' Obligations Under the International Health Regulations in Light of COVID-19 (Part I). Opinio Juris. Retrieved from http://opiniojuris.org/2020/03/31/covid-19-symposium-can-they-really-do-that-states-obligationsunder-the-international-health-regulations-in-light-of-covid-19-part-i/ [Accessed 10 May 2021]

World Health Organization (2005). International health regulations. Third report of Committee A, 58-th Wealth Assembly, A58/55, 5-60. Retrieved from https://apps.who.int/iris/rest/bitstreams/52146/retrieve [Accessed 15 May 2021]

World Health Organization (2020a). Recommendations for the public on infection with the new coronavirus COVID-19. Retrieved from https://www.who.int/ru/emergencies/diseases/novelcoronavirus-2019/advice-for-public [Accessed 12 May 2021]

World Health Organization (2020b). COVID-19 Strategy Update. Retrieved from https://krphc.org.ua/wp-content/uploads/2020/05/covid19-strategy-update-2020-ru.pdf [Accessed 04 May 2021]

World Health Organization (2020c). Timeline: WHO's COVID-19 response. Retrieved from https://www.who.int/emergencies/diseases/novel-coronavirus-2019/interactive-timeline [Accessed 22 May 2021]

World Health Organization (2020d). WHO Director-General's opening remarks at the media briefing on COVID-19. Retrieved from https://www.who.int/director-general/speeches/detail/who-directorgeneral-s-opening-remarks-at-the-media-briefing-on-covid-19---11-march-2020 [Accessed 22 May 2021]

Worldometers (2021). Covid-19 worldwide distribution statistics. Retrieved from https://www.worldometers.info/coronavirus/ [Accessed on 20 April 2021] 


\section{AUTHORS’ DECLARATIONS AND ESSENTIAL ETHICAL COMPLIANCES}

Authors' Contributions (in accordance with ICMJE criteria for authorship)

\begin{tabular}{|l|l|l|l|l|}
\hline Contribution & Author 1 & Author 2 & Author 3 & Author 4 \\
\hline Conceived and designed the research or analysis & Yes & Yes & Yes & Yes \\
\hline Collected the data & Yes & Yes & Yes & Yes \\
\hline Contributed to data analysis \& interpretation & Yes & No & No & Yes \\
\hline Wrote the article/paper & Yes & No & Yes & No \\
\hline Critical revision of the article/paper & Yes & Yes & No & No \\
\hline Editing of the article/paper & Yes & No & Yes & No \\
\hline Supervision & Yes & No & No & Yes \\
\hline Project Administration & Yes & Yes & No & No \\
\hline Funding Acquisition & No & No & No & No \\
\hline Overall Contribution Proportion $(\%)$ & 40 & 20 & 20 & 20 \\
\hline
\end{tabular}

Funding

No funding was available for the research conducted for and writing of this paper.

Research involving human bodies (Helsinki Declaration)

Has this research used human subjects for experimentation?

No

Research involving animals (ARRIVE Checklist)

Has this research involved animal subjects for experimentation?

Research involving Plants

No plant was used to conduct this research.

Research on Indigenous Peoples and/or Traditional Knowledge

Has this research involved Indigenous Peoples as participants or respondents? No

(Optional) PRISMA (Preferred Reporting Items for Systematic Reviews and Meta-Analyses)

Have authors complied with PRISMA standards? No

Competing Interests/Conflict of Interest

Authors have no competing financial, professional, or personal interests from other parties or in publishing this manuscript.

\section{RIGHTS AND PERMISSIONS}

Open Access. This article is licensed under a Creative Commons Attribution 4.0 International License, which permits use, sharing, adaptation, distribution and reproduction in any medium or format, as long as you give appropriate credit to the original author(s) and the source, provide a link to the Creative Commons license, and indicate if changes were made. The images or other third-party material in this article are included in the article's Creative Commons license, unless indicated otherwise in a credit line to the material. If material is not included in the article's Creative Commons license and your intended use is not permitted by statutory regulation or exceeds the permitted use, you will need to obtain permission directly from the copyright holder. To view a copy of this license, visit http://creativecommons.org/licenses/by/4.0/. 